\title{
Competitiveness of AleXandergrass OR Bengal Dayflower With SOYBEAN $^{1}$
}

\author{
Competitividade de Capim-Marmelada ou Trapoeraba com Soja \\ DIAS, A.C.R. ${ }^{2}$, CARVALHO, S.J.P. ${ }^{3}$, MARCOLINI, L.W. ${ }^{4}$, MELO, M.S.C. ${ }^{2}$ and \\ CHRISTOFFOLETI, P.J. ${ }^{5}$
}

\begin{abstract}
Weeds compete with field crops mainly for water, light and nutrients, and the degree of competition is affected by the weed density and the intrinsic competitive ability of each plant species in coexistence. The objective of this research was to compare the competitiveness of alexandergrass (Brachiaria plantaginea) or Bengal dayflower (Commelina benghalensis) in coexistence with soybean, cv. M-Soy 8045 . A factorial experiment (2 x 5) with two weed species and five competition proportions was carried out in a completely randomized design with four replicates. Proportions were based on a replacement series competition design, always maintaining the total density of four plants per $10 \mathrm{~L}$ plastic pots, which corresponded to 60 plants $\mathrm{m}^{2}$. The weed-crop proportions were: $0: 4 ; 1: 3 ; 2: 2 ; 3: 1 ; 4: 0$; that corresponded to the proportion of $100,75,50,25$ and $0 \%$ of soybean plants and the opposite for weeds, B. plantaginea or $C$. benghalensis plants. Leaf area, shoot dry mass of the weeds and soybean and number of soybean trifoliate leaves were evaluated when the soybean reached the phenologic stage of full flowering. B. plantaginea was a better competitor than soybean plants. Otherwise, $C$. benghalensis revealed a similar competitive ability that of the soybean. In both cases, there were evidences that intraspecific competition was more important.
\end{abstract}

Keywords: Glycine max, Brachiaria plantaginea, Commelina benghalensis, competition, dry mass, substitutive series.

RESUMO - As plantas daninhas competem com as culturas por água, luz e nutrientes, sendo que o grau de competição é afetado pela densidade de infestação das plantas daninhas, bem como pela habilidade competitiva intrínseca de cada espécie em convivência. Assim sendo, o objetivo desta pesquisa foi comparar a competitividade do capim-marmelada (Brachiaria plantaginea) ou da trapoeraba (Commelina benghalensis) com a soja, cv. M-Soy 8045. Os tratamentos foram desenvolvidos em esquema fatorial $(2 \times 5)$ correspondendo a duas espécies de plantas daninhas em cinco proporções de plantas em competição. As proporções foram baseadas em modelos substitutivos de competição, mantendo-se sempre a densidade total de quatro plantas por parcela, que correspondeu à 60 plantas $m^{-2}$. As proporções de competição cultura-planta daninha foram: 0:4; 1:3; 2:2; 3:1; 4:0; que corresponderam às proporção de 100, 75, 50, 25 e 0\% de plantas de soja e o inverso de plantas de B. plantaginea ou de C. benghalensis. Foram avaliados a área foliar, massa seca da parte aérea das plantas daninhas e da soja e número de trifólios da soja, no estádio de pleno florescimento da soja. B. plantaginea foi melhor competidora que as plantas de soja. Por outro lado, C. benghalensis teve habilidade competitiva similar à soja. Em ambos os casos, houve evidências que a competição intraespecífica teve maiorimportância do que a competição interespecífica.

Palavras-chave: Glycine max, Brachiaria plantaginea, Commelina benghalensis, competição, massa seca, método substitutivo.

1 Recebido para publicação em 25.6.2009 e na forma revisada em 3.9.2010.

2 Engo-ó-Agr ${ }^{\circ}$, alunos do Programa de Pós-Graduação em Fitotecnia da Escola Superior de Agricultura "Luiz de Queiroz" - ESALQ/ USP, Caixa Postal 09, 13419-900 Piracicaba-SP, <anacarolina.r.dias@gmail.com>, <melomsc@yahoo.com.br>; ${ }^{3}$ Professor do Instituto Federal do Sul de Minas, Campus Machado <sjpcarvalho@yahoo.com.br>; ${ }^{4}$ Engo-Agr ${ }^{\circ}$., M.S., Representante de Vendas - Dow AgroSciences <LWMarcolini@dow.com>; ${ }^{5}$ Professor Associado do Departamento de Produção Vegetal, ESALQ/USP. <pjchrist@esalq.usp.br>, Caixa Postal 09, 13419-900 Piracicaba-SP.

Planta Daninha, Viçosa-MG, v. 28, n. 3, p. 515-522, 2010 


\section{INTRODUCTION}

When in coexistence with field crops, weeds compete directly for water, sunlight and soil nutrients; and may indirectly negatively interfere with crop management and harvest operations (Pitelli, 1985; López-Ovejero et al., 2007). Particularly for soybean crop (Glycine max), weed infestation during the early crop development might result in significant crop yield losses (Spadotto et al., 1994; Fleck et al., 2002) which are affected by the specific composition of the weed community and the competitive ability of the species in coexistence (Pitelli, 1985; Spadotto et al., 1992).

Traditionally, alexandergrass (Brachiaria plantaginea) has been pointed out as the most troublesome grass weed (Poaceae family) for soybean cropping areas in Brazil (Martins, 1994; Fleck et al., 2002). The direct damages to soybean yield are variable, however in fertile soils, $B$. plantaginea growth and development can be so vigorous that an infestation of one plant per square meter may reduce soybean yield up to $50 \%$ (Kissmann, 1997).

After the introduction of transgenic crops resistant to glyphosate in agriculture, the application of this herbicide increased significantly worldwide (Young et al., 2003; Christoffoleti et al., 2008) which resulted in the weed shift effect selecting glyphosatetolerant species (Johnson et al., 2002). For example, Bengal dayflower (Commelina benghalensis) is considered a "glyphosatehard-to-kill" weed and it has been correlated with species ability in metabolizing glyphosate to amino-methyl-phosphonic acid - AMPA (Monquero \& Christoffoleti, 2003; Monquero et al., 2004).

Glyphosate selection of Bengal dayflower population in Brazilian soybean cropping areas is recent and few studies were developed regarding this subject. Several methods have been used for studying competition between crop and weeds, however only quantifying the losses caused by weed interference on the crops is not enough. The comprehension of the competitive process in a mechanistic way is also important and several experimental designs can be used in order to infer the relationships among crops and weeds competitive ability (Christoffoleti \& Victoria Filho, 1996). In addiction, it is also important to include both the density and the proportion of the species into the models (van Acker et al., 1998).

Replacement series is an experimental design based on a constant total plant density in the pot and variable proportion of the two species or biotypes in competition (Harper, 1977). The isolated population of the species, called monocultures, is also included in the experiment, in the same density. The basic principle of this experimental design is to determine the yield of mixed competing species, and compare it with the yield of the monocultures. The assumption is that the total pot density is enough to capture all the resources available for growth considering the constant final yield law. The total dry mass production and leaf area are the basic variables to be evaluated when studying plant growth in these studies (Radosevich, 1997).

Thus, the objective of this research was to compare the competitiveness of $B$. plantaginea or $C$. benghalensis with soybean plants (cv. M-Soy 8045) and analyzing the importance of intra and interspecific competition for these species.

\section{MATERIAL AND METHODS}

The experiment was carried out in the greenhouse located in Piracicaba, State of São Paulo - SP, Brazil (22 42' 30" S, 47 $38^{\circ}$ ' 00" W and $546 \mathrm{~m}$ of altitude), from January to March, 2008. Alexandergrass (Brachiaria plantaginea) and Bengal dayflower (Commelina benghalensis) were the species analyzed in competition with the soybean crop. Initially, weeds were seeded in $2.0 \mathrm{~L}$ plastic pots filled with Plantimax ${ }^{\circledR}$ substrate (Pinus bark + turf + vermiculite) in order to get plants at the phenological stage of one true leaf. For achieving plants of both weed species plants at the same phenological stage (one true leaf) in the same day, $C$. benghalensis was seeded 5 days prior to $B$. plantaginea. When the weeds were ready for transplanting, the pots were set. Soybean was equidistantly seeded directly in the pots, $0.03 \mathrm{~m}$ depth, and right after weed transplantations. 
The soybean cultivar used was M-Soy 8045, and its seeds were previously treated with the insecticide fipronil (Standak ${ }^{\circledR}$ ) and with the fungicides carbendazin + thiram (Derosal Plus ${ }^{\circledR}$ ), both at the rate of $200 \mathrm{~mL}$ of commercial product per $100 \mathrm{~kg}$ of seeds. After the seed care, they were shadow-dried and inoculated with turf-commercial inoculant (Bradyrhizobium japonicum - SEMIA $5079+$ SEMIA 5019) in the rate of $400 \mathrm{~g}$ per $100 \mathrm{~kg}$ of seeds. For soybean, two seeds were distributed at each desired position, and after soybean emergence one seedling was thinned out maintaining one plant per correspondent position.

The experimental units consisted of $10 \mathrm{~L}$ plastic pots, filled with a mixture of mediumtextured soil and the commercial substrate Plantimax $^{\circledR}(2: 1)$, fertilized with five grams of the formula 8-28-16 $\left(\mathrm{N}-\mathrm{P}_{2} \mathrm{O}_{5}-\mathrm{K}_{2} \mathrm{O}\right)$. Soil chemical and physical properties were: $\mathrm{pH}$ $\left(\mathrm{CaCl}_{2}\right)$, 5.2; organic matter, $65 \mathrm{~g} \mathrm{dm}^{-3}$; P resin, $99 \mathrm{mg} \mathrm{dm}^{-3}$; K, Ca, Mg, $\mathrm{Al}$ and CEC, 19.4, 68, 25, 2 and $154 \mathrm{mmol}_{\mathrm{c}} \mathrm{dm}^{-3}$, respectively; V, 73\%; $\mathrm{m}, 2 \%$; clay, silt and total sand (coarse + fine), 293, 247, $460(220+240) \mathrm{g} \mathrm{kg}^{-1}$, respectively. The pots were irrigated by automated aspersion in order to avoid any water deficit for the normal growth of the plants.

A factorial experiment with two weed species and five competition proportions was carried out in a completely randomized design with four replicates. The proportions were based on a replacement series competition design (Cousens, 1991), always maintaining the total density of four plants per pot, uniformly distributed, that was equivalent to the density of 60 plants $\mathrm{m}^{-2}$. The soybean: weed proportions were: 4:0, 3:1, 2:2, $1: 3$ and $0: 4$, corresponding to $100,75,50,25$ and $0 \%$ of soybean plants, and the inverse of alexandergrass or Bengal dayflower plants, i.e., 0, 25, 50, 75 e 100\%, respectively. The percentage values also identify the expected yield of each species, if competitively equivalent.

All the variables were evaluated when flowering phenological stage was observed for soybean, that was identified at 60 days after emergence (DAE). The total number of soybean trifoliate leaves per pot was counted. After that, the plants were cut at the level of the substrate in the pot, separately for each species. The leaf area $\left(\mathrm{cm}^{2}\right.$ per pot) was obtained with the area meter model LICOR LI-3100 (LI-COR, inc., Lincoln, Nebraska, EUA). The shoot dry mass (g per pot) of each species was obtained after drying the samples at $70{ }^{\circ} \mathrm{C}$ for $72 \mathrm{~h}$.

The observed relative yields were calculated by dividing the observed production in the different proportions by the mean yield of the pots maintained only with their own species (monoculture) and multiplying by 100 (De Wit \& Berg, 1965; McGilchrist \& Trenbath, 1971; Harper, 1977; Carvalho \& Christoffoleti, 2008). Data were analyzed through the application of ' $F$ ' test on variance analyses $(\alpha=$ $0.05)$. When qualitative effects were observed, they were compared by ' $t$ ' test $(\alpha=0.05)$. Polynomial regressions were used to fit quantitative effects (proportions). In addiction, proportions were submitted to conventional analyses for replacement series (Radosevich, 1987).

\section{RESULTS AND DISCUSSION}

The weed-proportion factorial interaction was identified for all soybean variables, such as shoot dry mass, leaf area and relative number of trifoliate leaves (Table 1). For all the variables, soybean competition with $B$. plantaginea resulted in higher yield losses when compared to soybean $-C$. benghalensis competition. The differentiation by ' $t$ ' test indicated that $B$. plantaginea was more efficient than $C$. benghalensis in using the growth resources available in the environment, presenting higher competitive potential to reduce soybean development (Table 1). Polynomial equations were adequate to fit the variables (Table 2). These equations indicated the variable behavior and could be used for modeling species response when in competition, and they were also able to contribute to comparative discussions with other experiments.

A determined plant species is considered an efficient competitor when it rapidly uses some environmental resource or when it is able to keep developing even with few resources available in the environment (Radosevich, 1997). B. plantaginea competitiveness is attributed, among other factors, to the 
Table 1 - Relative values of soybean (cv. M-Soy 8045) shoot dry mass, leaf area and number of trifoliate leaves, when submitted to different competitive proportions with Brachiaria plantaginea (BRAPL) and Commelina benghalensis (COMBE), in fixed density of 60 plants $\mathrm{m}^{-2}$. Piracicaba, SP, Brazil, 2008

\begin{tabular}{|c|c|c|c|c|c|c|}
\hline \multirow{2}{*}{$\begin{array}{c}\text { Soybean Expected } \\
\text { Yield }(\%)\end{array}$} & \multicolumn{2}{|c|}{ Shoot Dry Mass ${ }^{1 /}$} & \multicolumn{2}{|c|}{ Leaf Area } & \multicolumn{2}{|c|}{ Trifoliate Leaves } \\
\hline & BRAPL & COMBE & BRAPL & COMBE & BRAPL & COMBE \\
\hline 100 & $100.0 \mathrm{a}$ & $100.0 \mathrm{a}$ & $100.0 \mathrm{a}$ & $100.0 \mathrm{a}$ & $100.0 \mathrm{a}$ & $100.0 \mathrm{a}$ \\
\hline 75 & $47.4 \mathrm{~b}$ & $75.4 \mathrm{a}$ & $27.6 \mathrm{~b}$ & $60.9 \mathrm{a}$ & $33.6 \mathrm{~b}$ & $73.0 \mathrm{a}$ \\
\hline 50 & $41.9 \mathrm{~b}$ & $61.9 \mathrm{a}$ & $20.5 \mathrm{~b}$ & $45.8 \mathrm{a}$ & $22.6 \mathrm{~b}$ & $47.0 \mathrm{a}$ \\
\hline 25 & $30.3 \mathrm{~b}$ & $45.7 \mathrm{a}$ & $6.11 \mathrm{~b}$ & $25.7 \mathrm{a}$ & $8.9 \mathrm{~b}$ & $26.6 \mathrm{a}$ \\
\hline $\mathrm{F}_{\text {(int) }}$ & \multicolumn{2}{|c|}{$5.082 * *$} & \multicolumn{2}{|c|}{$3.575^{*}$} & \multicolumn{2}{|c|}{$5.047 * *$} \\
\hline $\mathrm{CV}(\%)$ & \multicolumn{2}{|c|}{8.24} & \multicolumn{2}{|c|}{20.26} & \multicolumn{2}{|c|}{15.70} \\
\hline
\end{tabular}

${ }^{1 /}$ Averages followed by the same letter, in the line, are not different according to ' $t$ ' test, with $5 \%$ of confidence. Original data presented, however previously transformed by $\sqrt{x+0.5}$; *Significant at $5 \%$; * Significant at $1 \%$.

Table 2 - Adjustment of relative shoot dry mass, leaf area and number of trifoliate leaves of soybean plants and weed species to competing proportions. Piracicaba, SP, Brazil, 2008

\begin{tabular}{|c|c|c|c|}
\hline Species & Variable & Equations & $\mathrm{R}^{2}$ \\
\hline \multicolumn{4}{|c|}{ Competition Soybean : B. plantaginea } \\
\hline \multirow{3}{*}{ Soybean } & Shoot Dry Mass & $y=-0.0003 x^{3}-0.0477 x^{2}+2.2838 x$ & 0.9955 \\
\hline & Leaf Area & $y=0.0132 x^{2}-0.3907 x$ & 0.9289 \\
\hline & Trifo liate Leaves & $y=0.0118 x^{2}-0.2410 x$ & 0.9463 \\
\hline \multirow{2}{*}{ B. plantaginea } & Shoot Dry Mass & $y=-0.0349 x^{2}+4.4212 x$ & 0.9394 \\
\hline & Leaf Area & $\mathrm{y}=-0.0251 \mathrm{x}^{2}+3.4382 \mathrm{x}$ & 0.8918 \\
\hline \multicolumn{4}{|c|}{ Competition Soybean : C. benghalensis } \\
\hline \multirow{3}{*}{ Soybean } & Shoot Dry Mass & $y=-0.0062 x^{2}+1.5782 x$ & 0.9665 \\
\hline & Leaf Area & $y=0.9334 x$ & 0.9764 \\
\hline & Trifoliate Leaves & $y=0.9861 x$ & 0.9980 \\
\hline \multirow{2}{*}{ C. benghalensis } & Shoot Dry Mass & $\mathrm{y}=1.0294 \mathrm{x}$ & 0.9483 \\
\hline & Leaf Area & $y=0.0003 x^{3}-0.0516 x^{2}+3.4230 x$ & 0.9996 \\
\hline
\end{tabular}

* Where: $x$ represents the percentage of species participation in the competition, varying between 0 and $100 \%$; and $y$ represents the percentage response of the variable.

production of high amount of seeds, to germination distributed with the crop cycle, to the morphology that results in a vigorous leaf canopy over the soybean (Martins, 1994) and to $\mathrm{C} 4$ cycle of carbon assimilation (Kissmann, 1997). The results described in Figure 1 are in agreement with these studies and also characterize $B$. plantaginea as a better competitor than soybean crop, mainly in the proportion 50:50 which is the point that clearly indicates which was the best competitor. In general, for the weed observed the relative shoot dry mass and the leaf area were always higher than the expected values.
For both species, there were evidences that intraspecific competition was more important than interspecific competition. For example, for shoot dry mass and leaf area, the highest negative deviation of soybean observed yield was identified when the crop represented $75 \%$ of the pot; on the other hand, the lowest positive deviation of $B$. plantaginea was also observed when the species represented $75 \%$ of the pot (Figure 1). Identification of intraspecific competition suggests differentiated necessity of the species for growth resources and it may also characterize different ecologic niches. Some 
plant characteristics that determine high species competitiveness are: plant size and architecture, speed of growth and root system extension, the lower susceptibility to climatic adversities, the higher leaf area index, and the ability to produce and to spread compounds with allelopathic activity (Silva et al., 2004).

A sequential reduction of soybean grain yield was observed when the crop was submitted to competition with progressive weed densities (Voll et al., 2002). The weed species B. plantaginea, Ipomoea grandifolia, Euphorbia heterophylla and Senna obtusifolia reduced the crop production in a distinct way, up to $19,25,32$ and $47 \%$, respectively. Similar results were obtained by Klingaman \& Oliver (1994) and Bensch et al. (2003) when soybean - pigweed (Amaranthus) competition was established. Different results were found by Passini et al. (2003) who studied competition of common beans (Phaseolus vulgaris) with B. plantaginea. The common bean was a better competitor than alexandergrass and the intraspecific competition was more significant to species than interespecific, the competition between common bean plants was more intense than the competition established between the crop and alexandergrass. However, it is important to point out that the common bean high competitive ability might be explained by its emergence before the weed species.
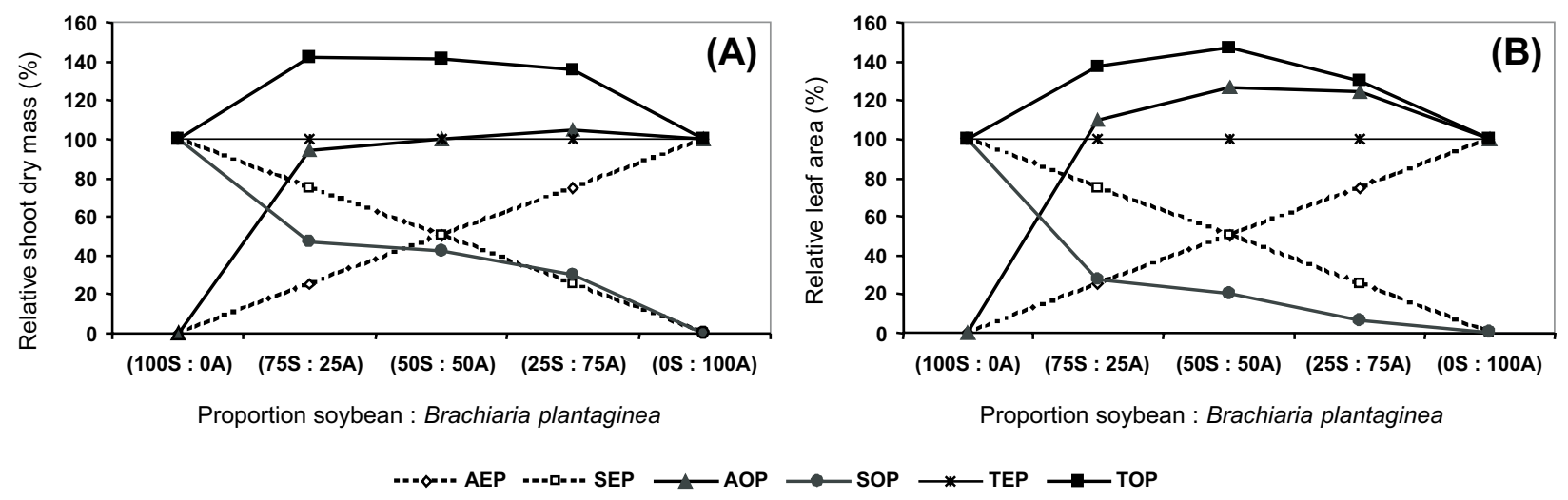

In addition to the glyphosate tolerance, C. benghalensis has high spreading efficiency, both through seeds produced by alogamic (aerial seeds) and cleistogamic flowers (underground seeds), and through vegetative parts of the stems. These characteristics make the control difficult and allow the species to survive in different environments (Walker \& Evenson, 1985; Gonzalez \& Haddad, 1995; Santos et al., 2001). The competitive ability of $C$. benghalensis was similar to that of the soybean plants for the variable dry mass, since both lines are almost coincident with the equivalence line (dashed lines) in the Figure 2A. For the variable leaf area, an advantage for weed species was observed, when it is part of the proportion in the mixture (Figure 2B). Therefore it can be inferred for the competitive interaction between C. benghalensis and soybean that intraspecific competition was more important than interespecific competition, and the species competitive ability are similar (Figure 2).

High competitive ability of the crops was found, indicating that the density of weed infestation has a bigger importance than their intrinsic competitiveness. For example, Rizzardi et al. (2004) analyzed I. ramosissima on soybean crop. Both weed species and soybean produced shoot dry mass amounts over than expected. The soybean isolated interference of $E$. heterophylla and

$\mathrm{AEP}=$ alexandergrass expected production; $\mathrm{SEP}=$ soybean expected production; $\mathrm{AOP}=$ alexandergrass observed production; $\mathrm{SOP}=$ soybean observed production; TEP $=$ total expected production; TOP $=$ total observed production.

Figure 1 - Relative shoot dry mass (A) and leaf area (B) of soybean and alexandergrass (Brachiaria plantaginea), when submitted to different competitive proportions in fixed total density of 60 plants $\mathrm{m}^{-2}$. Dashed lines represent no-interaction hypothesis. Piracicaba, SP, Brazil, 2008. 

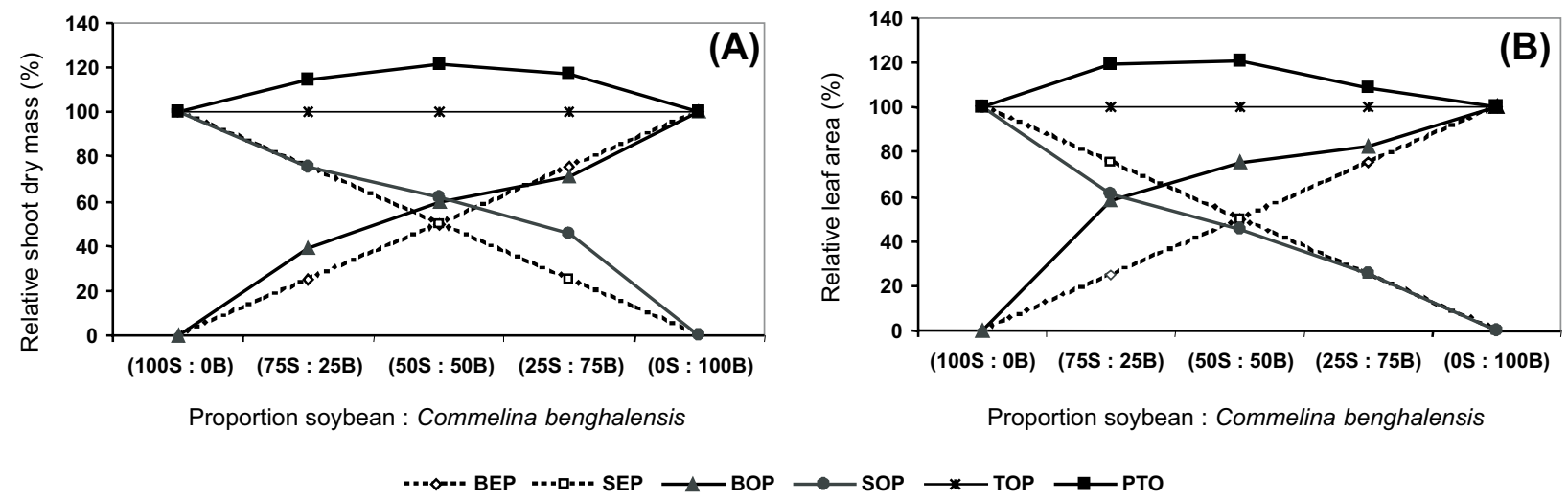

$\mathrm{BEP}=$ Bengal dayflower expected production; $\mathrm{SEP}=$ soybean expected production; $\mathrm{BOP}=$ Bengal dayflower observed production; $\mathrm{SOP}=$ soybean observed production; $\mathrm{TEP}=$ total expected production; $\mathrm{TOP}=$ total observed production

Figure 2 - Relative shoot dry mass (A) and leaf area (B) of soybean and Bengal dayflower (Commelina benghalensis), when submitted to different competitive proportions, in fixed total density of 60 plants $\mathrm{m}^{-2}$. Dashed lines represent no-interaction hypothesis. Piracicaba, SP, Brazil, 2008.

mass reduction was more intense in the presence of I. ramosissima, and in situations in which the weed was established before the crops in the pots. López-Ovejero et al. (2007) comparing competitive ability of crabgrass biotypes (Digitaria ciliaris) with the soybean crop through the replacement series method also reported better competitiveness of the crop. The delay of seven days in soybean sowing increased the competitiveness of crabgrass plants, although it was not enough to invert the competitive response. In addition, another research found that dry bean was better competitor than each one of five pigweed species (Amaranthus spp.), using a replacement series design with the total density of 80 plants $\mathrm{m}^{-2}$ (Carvalho \& Christoffoleti, 2008).

These results of the present study are in agreement with Christoffoleti \& Victoria Filho (1996) who used the replacement series method to evaluate interespecific competition of the corn crop (Zea mays) with A. retroflexus, in density equivalent to 400 plants $\mathrm{m}^{-2}$. Maize was a much more efficient competitor than pigweed; for the crop, the intraspecific competition was more important than the interspecific competition. The opposite was also true for pigweed, i.e., interspecific competition was more important for the species.

The soybean ability to compete with weeds might be attributed to cultivar growth characteristics, like speed of emergence, plant height, mass accumulation, and canopy architecture (Shaw et al., 1997). In addition, the crop spatial distribution is also important, once light is one of the resources that weeds most compete for with the crops. Critical characteristics of light competition include the fast speed of growth and plant height (Lindquist et al., 1998).

In conclusion, $B$. plantaginea was a better competitor than soybean plants, however for C. benghalensis the competitive ability proved similar to that of the soybean plants. In both cases, the intraspecific competition was more important than interspecific competition.

\section{ACKNOWLEDGEMENTS}

To CAPES - Brazil for the financial support to this research.

\section{LITERATURE CITED}

BENSCH, C. N.; HORAK, M. J.; PETERSON, D. Interference of redroot pigweed (Amaranthus retroflexus), Palmer amaranth (A. palmerii), and common waterhemp (A. rudis) in soybean. Weed Sci., v. 51, n. 1, p. 37-43, 2003

CARVALHO, S. J. P.; CHRISTOFFOLETI, P. J. Competition of Amaranthus species with dry bean plants. Sci. Agric., v. 65, n. 3, p. 239-245, 2008

CHRISTOFFOLETI, P. J. et al. Glyphosate sustainability in South American cropping systems. Pest Manag. Sci., v. 64, n. 4, p. 422-427, 2008. 
CHRISTOFFOLETI, P. J.; VICTORIA FILHO, R. Efeitos da densidade e proporção de plantas de milho (Zea mays L.) e caruru (Amaranthus retroflexux L.) em competição

Planta Daninha, v. 14, n. 1, p. 42-47, 1996.

COUSENS, R. Aspects of the design and interpretation of competition (interference) experiments. Weed Technol., v. 5, n. 3, p. 664-673, 1991.

DE WIT, C. T.; BERG, J. P. V. D. Competition between herbage plants. Nether. J. Agric. Sci., v. 13, p. 212-221, 1965.

FLECK, N. G. et al. Período crítico para controle de Brachiaria plantaginea em função de épocas de semeadura da soja após dessecação da cobertura vegetal. Planta Daninha, v. 20, n. 1, p. $53-62,2002$.

FLECK, N. G. et al. Interferência de picão preto e guanxuma com a soja: efeitos da densidade de planta e época relativa de emergência. Ci Rural, v. 34, n. 1, p. 41-48, 2004.

GONZALEZ, C. B.; HADDAD, C. R. B. Efeito da luz e temperatura na floração e germinação de sementes de Commelina benghalensis L. Arq. Biol. Tecnol., v. 38, n. 2, p. 651-659, 1995.

HARPER, J. L. Mixtures of species. I. Space and proportions. In: HARPER. J. L. (Ed.). Population biology of plants. 8.ed. London: Academic Press, 1977. p. 237-276.

JOHNSON, B. F. et al. Herbicide effects on visible injury, leaf area, and yield of glyphosate-resistant soybean (Glycine max). Weed Technol., v. 16, n. 3, p. 554-566, 2002.

KISSMANN, K. G. Plantas infestantes e nocivas. 2.ed. São Paulo: BASF, 1997. Tomo 1. 825 p.

KLINGAMAN, T. E.; OLIVER, L. R. Palmer amaranth (Amaranthus palmerii) interference in soybean (Glycine max). Weed Sci., v. 42, n. 4, p. 523-527, 1994.

LÓPEZ-OVEJERO, R. F. et al. Crescimento e competitividade de biótipos de capim-colchão resistente e suscetível aos herbicidas inibidores da acetil coenzima A carboxilase. Pesq. Agropec. Bras., v. 42, n. 1, p. 1-8, 2007.

LINDQUIST, J. L.; MORTENSEN, D. A.; JOHNSON, B. E. Mechanisms of corn tolerance and velvetleaf suppressive ability. Agron. J., v. 90, n. 6, p. 787-792, 1998.

MARTINS, D. Interferência de capim-marmelada na cultura da soja. Planta Daninha, v. 12, n. 1, p. 93-99, 1994

McGILCHRIST, C. A.; TRENBATH, B. R. A revised analysis of plant competition experiments. Biometrics, v. 27, p. $659-671,1971$.
MONQUERO, P. A.; CHRISTOFFOLETI, P. J. Dinâmica do banco de sementes em áreas com aplicação freqüente do herbicida glyphosate. Planta Daninha, v. 21, n. 1, p. 63-69, 2003.

MONQUERO, P. A. et al. Absorção, translocação e metabolismo do glyphosate por plantas tolerantes e suscetíveis a este herbicida. Planta Daninha, v. 22, n. 3, p. $445-451,2004$.

PASSINI, T:; CHRISTOFFOLETI, P. J.; YADA, I. F. U. Competitivity of the common-bean plant relative to the weed alexandergrass [Brachiaria plantaginea (Link) Hitch.]. Sci. Agric., v. 60, n. 2, p. 259-268, 2003.

PITELLI, R. A. Interferência de plantas daninhas em culturas agrícolas. Inf. Agropec., v. 11, n. 129, p. 16-27, 1985

RADOSEVICH, S. R. Methods to study interactions among crops and weeds. Weed Technol., v. 1, n. 1, p. 190-198, 1987.

RADOSEVICH, S. Physiological aspects of competition. In: RADOSEVICH, S.; HOLT, J. S.; GHERSA, C. (Eds.). Weed ecology: implications for vegetation management. 2.ed. New York: John Willey \& Sons, 1997. p. 217-301.

RIZZARDI, M. A et al. Interferência de populações de Euphorbia heterophylla e Ipomoea ramosissima isoladas ou em misturas sobre a cultura de soja. Planta Daninha, v. 22, n. 1, p. 29-34, 2004

SANTOS, I. C. et al. Eficiência do herbicida glyphosate no controle de Commelina benghalensis e Commelina diffusa.

Planta Daninha, v. 19, n. 1, p. 135-143, 2001.

SILVA, A. A.; JAKELAITIS, A.; FERREIRA, L. R. Manejo de plantas daninhas no sistema integrado agricultura-pecuária In: ZAMBOLIM, L.; SILVA, A. A.; AGNES, E. L. (Eds.). Manejo integrado: integração lavoura-pecuária. Viçosa, MG: Universidade Federal de Viçosa, 2004. p. 117-170.

SHAW, D. R.; RANKINS Jr., A.; RUSCOE, J. T. Sicklepod (Senna obtusifolia) interference with soybean (Glycine max) cultivars following herbicide treatments. Weed Technol., v. 11, p. 510-514, 1997.

SPADOTTO, C. A. et al. Determinação do período crítico para prevenção da interferência de plantas daninhas na cultura da soja: uso do modelo "broken-stick". Planta Daninha, v. 12, n. 1, p. 59-62, 1994.

SPADOTTO, C. A. et al. Avaliação de parâmetros para o monitoramento da interferência de plantas daninhas na cultura da soja (Glycine max L.). Planta Daninha, v. 10, n. 1, p. 33-38, 1992. 
van ACKER, R. A.; LUTMAN, P. J. W.; FROUDWILLIAMS R. J. Additive infestation model (AIM) analysis for the study of two-weed species interference. Weed Res., v. 38, p. 275-281, 1998.

VOLL, E. et al. Competição relativa de espécies de plantas daninhas com dois cultivares de soja. Planta Daninha, v. 20, n. 1, p. $17-24,2002$.
WALKER, S. R.; EVENSON, J. P. Biology of Commelina benghalensis L. in South-Eastern Queensland. 1. Growth, development and seed production. Weed Res., v. 25, n. 4, p. 239-244, 1985.

YOUNG, B. G. et al. Glyphosate translocation in common lambsquarters (Chenopodium album) and velvetleaf (Abutilon theophrasti) in response to ammonium sulfate. Weed Sci., v. 51, n. 2 , p. 151-156, 2003. 